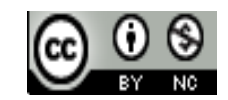

Journal of Education, Teaching and Learning is licensed under A Creative Commons Attribution-Non Commercial 4.0 International License.

\title{
Developing Authentic Assessment Instrument on Short Story Appreciation and Production for Senior High School Students
}

\author{
Purwadi Susilo $^{1)}$, Ratu Wardarita ${ }^{2)}$ \\ 1) SMA YPI Tunas Bangsa, Palembang, South Sumatera, Indonesia \\ Email:purwadis2006@yahoo.co.id \\ ${ }^{2 \jmath}$ Universitas PGRI Palembang, South Sumatera, Indonesia. \\ Email:ratuwardarita@yahoo.com
}

\begin{abstract}
This study was conducted as the follow-up action toward the result of a preliminary study which showed that Indonesian Language teachers in Senior High School (mentioned as "SMA") YPI Tunas Bangsa Palembang had not yet implemented any standardized, objective, accurate nor appropriate assessment instruments as demanded by the 2013 curriculum. Based on this problem, the research question in this study was "How are teachers' necessities of an authentic assessment instrument to assess understanding on the short stories production and appreciation in SMA YPI Tunas Bangsa Palembang?". This study employed the research and development method adapted from the one proposed by Akker which consisted of several steps: (1) analysis, (2) design, (3) evaluation, and the one by Tessmer: (1) self-evaluation, (2) expert judgment, (3) one-to-one, (4) small group, (5) revision, and (6) field test. The implementation of the authentic assessment for short stories production and appreciation was analyzed by using the inter-rater agreement. The inter-rater reliability was measured using the Cronbach's Alfa. The data were also analyzed using the SPSS 16 program which resulted to a level of significance at 0.5 . Therefore, it is found that the evaluation given by the experts and the respondents reached a similar perception. Based on the result of the Cronbach's Alpha test, a value of 0.99 was obtained above 0.70 which implies that the authentic assessment instruments developed in this study are highly reliable.
\end{abstract}

Keywords: authentic assessment, short stories appreciation and production

\section{INTRODUCTION}

Assessment is an important part of teaching and learning activities at schools. Any teaching and learning activity should be followed by appropriate assessment or evaluation. Assessment is done to measure the success of the teaching activity and to see students' understanding of the learning materials. The 2013 curriculum emphasizes on the implementation of the authentic assessment system. Authentic assessment should be made upon the real condition or context which refer to students' real knowledge and skills. Kunandar [1] stated that authentic assessment focuses on what to assess, including the process and the results using a set of instruments which are constructed based on the Core Competence and Basic Competence of the teaching and learning activity. Appreciation is one of the goals in Indonesian language teaching. The teaching of literature appreciation especially short stories demands a deep understanding of the structure and the values of the short stories. To measure students' understanding of the structure and the values of short stories, assessment instruments should be used.

Previous research relevant to this research is a study conducted by Vina Fatimah Agustina [2] entitled "Development of Novel Appreciation Listening Appraisal on Indonesian Language Subject for Junior High School Grade VII Semester 2". The goal is to describe the profile of the test kit, to explain the validity and reliability of test questions, to explain the students' response to the test kits, and to explain the expert's response to the novel appreciative skill listening skill on Indonesian Language subjects at SMPN 1 Bandung. The result of the research and development is a set of novel appreciative listening evaluation tools developed by using quiz creator application (Macromedia flash). The number of questions on the test equipment developed amounted to 30 grains. The validity of the test instrument can be said high with coefficient value 0.631 . In addition, this test is also said to have a highly reliable level, ie with a value of 0.774 . Of 
the 30 questions created there are 16 or $53 \%$ of valid declared questions. Evaluation tools developed categorically practical, interesting, positive impact on psychology, and can measure students' appreciative listening ability.

The equation of previous research with this research is equally research development of assessment tool. But in this study, more focus on the problem of developing an authentic assessment tool. Authentic assessment is a way of assessing abilities based on the conditions that the learners have. The difference lies in the developed material and the subject of research. In the research Agustina (2013), the material developed listening appreciative novel for VIII class 2nd semester while the research material developed is the appreciation and production of short stories for class XI.

The next prior and more relevant research is the "Development of a Nonfiction Writing Writing Abstract Writing Rubric in the Indonesian Language at SMA Negeri 3 Pagaralam" by Lusi Suriani [3]. This study aims to produce a scoring rubric for writing non-fiction writing of Indonesian subjects that are appropriate to the needs of teachers, valid, practical, and feasible to be used by Indonesian teachers in SMA Negeri 3 Pagaralam. This research and development uses research and development method by adapting Borg and Gall development model which consists of seven main steps, namely (1) research and information gathering, (2) planning, (3) development of initial product format, (4) initial field testing, (5) major product revisions, (6) primary field tests, (7) revisions of operational products. The application of the scoring rubric of non-fiction writing of high school Indonesian subjects in Pagaralam was analyzed using an inter-rater agreement. The calculation of the inter-rater reliability level is calculated using Cronbach's Alfa. In the analysis phase used SPSS 16 software with a significance level of 0.5 . The results showed that the application of the assessment rubric between the experts and researchers showed a similarity or similarity perception. Based on the test Cronbach's Alpa on the table looks at the number 0.99 and position the figure above 0.70 . This means the assessment rubric developed by the researcher is very reliable. Conclusion The scoring rubric of nonfiction writing is valid, reliable, practical, and feasible and the use of rubrics is believed to assist teachers in assessing nonfiction written by students objectively, accurately and reliably.

The similarity with this research is equally developed assessment rubric to assess the learning activity of Indonesian language. The difference lies in the material development, previous research develops rubric assessments of non-fiction writing skills while in this study focus on the development of an authentic appraisal apparatus and short story production.

The short story is one of the materials to teach the $11^{\text {th }}$-grade students as contained in the Indonesia's 2013 Curriculum that should be delivered in the academic years of 2014/2015 all over the nation. Consequently, most teachers had not yet had any idea on how to deliver this material especially on how to assess this competency. The only available assessment instrument in 2013 curriculum was a set of the rubric used to assess any competence of short story teaching.

Based on those facts, the primary objective of this study is to investigate teachers' necessities toward authentic assessment instruments to assess students' understanding of the appreciation and production of short stories as developed in Sekolah Menengah Atas (Senior High School; abbreviated as "SMA") YPI Tunas Bangsa Palembang. The primary objective is then broken down into sub-objectives as follows: (1) to investigate the validity of the developed instruments, (2) to find out the reliability of the developed instrument in this study, and (3) to investigate the practicality of the instruments developed in this study.

\section{RESEARCH METHOD}

This study employed a research and development method adapted from the one proposed by Akker [4] which consisted of some steps: (1) analysis, (2) design and (3) evaluation. In the product evaluation, the researcher adapted a formative evaluation procedure introduced by Tessmer [5] that included several development steps; (1) self-evaluation, (2) expert judgement, (3) one-to-one, (4) small group, (5) revision, dan (6) field test. However, the third step 3, that is, one-to-one, was eliminated in this study considering the fact that the instrument was developed for teachers.

\section{RESULTS AND DISCUSSIONS \\ A. Research Results \\ 1) Identification of Teachers' Needs}

Based on the result of the teachers' needs of an authentic assessment instrument to teach short story appreciation and production in SMA YPI Tunas Bangsa Palembang, teachers shared similar needs. Teachers wished to be provided with authentic assessment instrument completed with clear assessment method, assessment category, scoring, quality gradation, scoring criteria and standard assessment procedure that can be used to measure students' appreciation and production of short stories.

Teachers regarded the use of authentic assessment important since it is seen as (1) a guide to implement authentic evaluation on the production and appreciation of short stories, (2) it helps teachers to evaluate students' competence in a more detailed, holistic, efficient, accurate and objective way, (3) it motivates students to study harder and improve their learning strategy in the classroom.

In addition, the authentic assessment instrument demanded by the teachers should in the form of analytical rubric that includes: (1) introduction, (2) authentic assessment components of students' competence on short story production and appreciation, (3) procedure of using the instruments, (4) general preview of core 
competence/basic competence measured in the instrument. Teachers also demanded that the instrument should be complete to measure students' competence on short story production and appreciation. Meanwhile, teachers stated that they found difficulties related to the use of available authentic assessment instrument especially in determining the score and appropriate scoring criteria that match with the aspects being measured.

\section{2) The Prototype of the Developed Authentic Assessment Instrument}

The next step was the product development in the form of "Authentic Assessment Instruments of Short Story Production and Appreciation for Indonesian Language Course in High School". The developed product contains two parts; introduction part includes (1) cover page containing writer's identity, title, institution identity, and year, (2) cover page inside, (3) forward, (4) list of content and (5) list of table. The content of the authentic assessment instrument contains an introduction and the instrument itself.

The component of the authentic assessment instrument on short story production and appreciation covers Basic Competence 3.1 on the ability to understand the structure of short story, Basic Competence 3.5 on the ability to evaluate short story based on the text structure, Basic Competence 4.1 on the ability to interpret the message of a short story, Basic Competence 4.3 on the ability to compose a short story based on the appropriate structure, Basic Competence 4.3 on the ability to edit a short story based on the correct structure, Basic Competence 4.4 on the ability to make a review of a short story and Basic Competence 4.5 on the ability to convert a short story into other text types.

The instrument is also completed with a part that explains the procedure of how to use the authentic assessment instrument.

\section{3) Results of Expert Validation}

Expert validation involved an expert of assessment, expert of content and expert of language. The expert of the assessment aspect is a lecturer of Graduate Program of Indonesian Language Teaching, PGRI University Palembang. The expert of content and expert of language are lecturers of the Faculty of Language and Teacher Training, Sriwijaya University.

The expert validation shows this following result on the appropriateness of the product, $\mathrm{BC} 3.1$ is categorized good with an average score of 83.15 , BC 3.2 is categorized good with an average score of $77.04, \mathrm{BC}$ 3.3 is categorized good with an average score of 77.78 , BC 3.4 is categorized good with an average score of $82.78, \mathrm{BC} 3.5$ is categorized good with an average score of 79.44 , BC 4.1 is categorized good with an average score of $76.48, \mathrm{BC} 4.2$ is categorized well with an average score of $77.04, \mathrm{BC} 4.3$ is categorized good with an average score of 77.59 , BC 4.4 is categorized good with an average score of 77.78 , and BC 4.5 is categorized well with an average score of 78.15 .

\section{4) Result of the Field Test}

A field test was administered in two sessions; preliminary session and main session. There were 6 teachers who participated as the subjects of the field test. The preliminary field test of the product was intended to obtain responses from the subjects on the developed product. The responses from the subjects show that (1) the authentic assessment instrument provides easiness for the teachers to assess students' competence on short story production and appreciation and (2) the product provides various benefits for the teachers and has been considered effective enough in helping students to identify their weaknesses on short story production and appreciation as shown by the score in each of the assessed aspects.

\section{5) Result of the Questionnaires}

The data obtained from the questionnaires distributed to 21 respondents show these following result. BC 3.1 is categorized good with an average score of 71.84 , BC 3.2 is categorized good with an average score of $74.46, \mathrm{BC} 3.3$ is categorized good with an average score of 74.28 , BC 3.4 is categorized good with an average score of 74.46 , BC 3.5 is categorized good with an average score of $72.97, \mathrm{BC} 4.1$ is categorized good with an average score of $73.27, \mathrm{BC} 4.2$ is categorized good with an average score of $74.34, \mathrm{BC} 4.3$ is categorized good with an average score of 74.76 , BC 4.4 is categorized good with an average score of 72.97, and BC 4.5 is categorized good with an average score of 73.11 .

\section{6) Result of Expert Validation and Respondents}

The result of the use of authentic assessment to evaluate students competence on short story production and appreciation from the expert and from the respondents show this following results. The score from 21 respondents and the experts for $\mathrm{BC} 3.1$ until $\mathrm{BC} 4.5$ shows that averagely $4 \%$ of the students are considered competence enough, $69.1 \%$ are competent, and and $26.9 \%$ are considered highly competent. The lowest score obtained by the students is 60 and the highest one is 84 with average score of 72 .

\section{7) Inter-rater Reliability (Respondents)}

In this study, inter-rater reliability was measured using Cronbach's Alpha. The data were analyzed using the SPSS 16 program with the level of significance at 0.5 .

The Cronbach's Alpha test shows these following results. BC 3.1 on understanding the structure of short story shows value of 0.99 . BC 3.2 on comparing short stories show value of 0.99 , BC 3.3 on analyzing short stories at 0.99 , BC 3.4 on identifying short stories at 0.99 , BC 3.5 on evaluating short stories at 0.99 , BC 4.1 on interpreting short stories at $0.99, \mathrm{BC} 4.2$ on composing short stories at $0.99, \mathrm{BC} 4.3$ on editing short stories at 
0.99, BC 4.4 on composing short stories at 0.99 and $\mathrm{BC}$ 4.5 converting short stories to other text types at 0.99 . Overall, the results show value greater than 0.70 . Therefore, it can be concluded that the data obtained are strongly reliable.

\section{B. Discussion}

Based on the result of the needs analysis done to the Indonesian Language teachers in SMA YPI Tunas Bangsa Palembang, it can be seen that generally, teachers needed authentic assessment instruments. The teachers needed a set of an authentic assessment instrument that assesses students' competence on short story production and appreciation in a valid, accurate (reliable), practical and appropriate way, complete with a set of valid instruments and procedure on how to use the instrument. Teachers were in need of a ready-to-use authentic assessment instrument for they were lacking of time and skill on how to construct a set of authentic assessment instrument to measure students' competence on short story production and appreciation of Indonesian Language Course in high school. In order to create a set of valid, accurate (reliable), practical and appropriate authentic assessment instrument completed with scoring instrument and procedure, the researchers employed the theories proposed by Heaton [6] which were then adjusted to meet the users' real needs and adapted to the current curriculum applied by the school.

Assessment is a series of activities to acquire, analyze, and interpret data about the process and the learning outcomes of students who performed in a systematic and continuous, so that into meaningful information in decision-making (Djaali and Mulijono, 2008) [7]

The curriculum of 2013 requires the use of authentic assessment. In paradigmatic, authentic assessment requires embodiment of authentic learning (authentic instruction) and authentic learn (authentic learning). It is believed that authentic assessments are more capable to provide information about the ability of learners holistically and valid (Permendikbud No. 104/2014)[8].

Assessment is an important part of learning. By doing the assessment, teachers as managers of learning activities can find out the capabilities of the learners. Based on the results of the assessment educators can make appropriate decisions to define the steps that must be done next. Results of the assessment can also provide motivation for learners to perform better. Assessment conducted must have the principle of justice, that learners are treated equally so not to harm anyone or group of learners that are assessed. In addition, the assessment should not distinguish between socio-economic background, culture, gender language, and religion. The assessment also part of the educational process that can stimulate and motivate learners to perform better in achieving the highest level according to his ability (Direktorat Pembinaan SMA, 2010) [9].

Seen from the point of the professionalism of the task of education, the assessment is one of the characteristics inherent in the professional educators. A professional educator always wanted feedback on the learning process does. This is done because one of the indicators of a successful learning is determined by the level of success achieved learners. Thus, the assessment results can be used as a measure of success in learning and feedback for educators to improve the quality of their lessons.

Authentic assessment is the process of gathering information by teachers about the progress and achievement of learning undertaken by learners through a variety of techniques that are able to express, to prove or to show exactly that learning objectives and abilities competencies have really mastered and achieved (Permendikbud No.59/2014) [10].

In Permend ikbud No. 104/2014 [8] stated that several principles that need to be considered in the assessment of authentic learning outcomes of students, among others:

1. The assessment process should be an integral part of the le a rning process.

2. The assessment should reflect the real world problem.

3. The assessment must use a variety of sizes,

methods and criteria in

accordance with the characteristics and essence of the learning experience.

4. The assessment must be holistic covering all aspects of the learning objectives.

Furthermore, assessment of learning outcomes by students should pay attention to the foll owing principles: (1) Valid, the assessment is based on data that reflect the ability of the measured; (2) Objectively, the assessment is based on procedures and clear criteria, not influenced by the subjectivity of the assessor; (3) Fair, that assessment does not favor or disfavor learners, and does not distinguish between socio-economic background, culture, religion, language, ethnicity, and gender; (4) Integrated, that assessment is an integral component of the learning activities; (5) Open, the assessment procedures, assessment criteria, basis for decision making can be known by an interested party; (6) Comprehensive and Continuous, which covers all aspects of competency assessment using a variety of appropriate techniques for monitoring the development of the ability of learners; (7) Systematically, the assessment carried out by following the plan and gradually standardized measures; and (8) using the reference criterion, namely the assessment is based on the size of the attainment of the set. Thus authentic assessment is a form of assessment that requires students to show attitude, using the knowledge and skills gained from learning in the conduct of the actual situation. In other words that the assessment authentic is the approach, 
procedures, and instruments of assessment processes and outcomes of learning of students in the application of the attitude (spiritual and social), the knowledge and skills gained in the form of assignment actual behavior or behavior to the level of similarity with the real world, or independent learning (Supardi, 2015) [11].

The most important thing to consider is the fact that authentic assessment instrument was seen a crucial aspect that helps teachers to improve their competence in evaluating and assessing students' competence. The prototype of authentic assessment instrument developed in this study covers 10 basic competencies (BC 3.1, 3.2, 3.3, $3.4,3.5,4.1,4.2,4.3,4.4$, and 4.5), completed with general explanation and procedure on how to use the instruments. The result of expert validation on the appropriateness of the product to measure students' competence of short story production and appreciation shows score 81.66.

Content validation of the product show a score of 82.50. Meanwhile, the result of validation with the expert of language, the language use in the instrument obtained a score 80.00. Therefore, based on the categorization as presented in Table 14, the developed product in the form of a set of authentic assessment instrument to measure students' competence on short story production and appreciation has been considered good and appropriate.

Based on the result of the main field test, the product has been considered beneficial in giving easier assessment procedure for the teachers and it enhances' teachers' ability to measure students' competences in a more objective, accurate and fair way. It is shown by the result of the questionnaires on BC 3.1 which obtained an average score of 71.84, BC 3.2 at $74.46, \mathrm{BC} 3.3$ at 74.2, $\mathrm{BC} 3.4$ at $73.27, \mathrm{BC} 3.5$ at $74.34, \mathrm{BC} 4.1$ at $74.76, \mathrm{BC} 4.2$ at $74.34, \mathrm{BC} 4.3$ at $74.76, \mathrm{BC} 4.4$ at 72.97 and $\mathrm{BC} 4.5$ at 74.10. Hence, the result of questionnaires distributed to the teachers after the implementation of authentic assessment instrument developed in this study shows that the product is effective and practical to use for measuring students'

The scores of the developed authentic assessment instrument for Indonesian Language course in high school are presented as follow. The average score of the questionnaires for $\mathrm{BC} 3.1$ is $72.25, \mathrm{BC} 3.2$ at $73.44, \mathrm{BC}$ 3.3 at $75.56, \mathrm{BC} 3.4$ at $75.51, \mathrm{BC} 3.5$ at $75.56, \mathrm{BC} 4.1$ at $74.29, \mathrm{BC} 4.2$ at $75.08, \mathrm{BC} 4.3$ at $73.68, \mathrm{BC} 4.4$ at 73.43 , $\mathrm{BC} 4.5$ at 73.41 . Those scores were then compared to the scores obtained by the students as rated by the expert which results an average score of 71.88 for $\mathrm{BC} 3.1,76.44$ for $\mathrm{BC} 3.2,71.11$ for $\mathrm{BC} 3.3,75.66$ for $\mathrm{BC} 3.4,77.22$ for $\mathrm{BC} 3.5,74.11$ for $\mathrm{BC} 4.1,74.22$ for $\mathrm{BC} 4.2,72.66$ for $\mathrm{BC}$ 4.3, 73.88 for BC 4.4 and 73.11 for $\mathrm{BC} 4.5$.

By comparing the responses from experts and from respondents, it can be concluded that (1) there is a suitability between the evaluation given by the experts and the responses from 21 respondents toward 3 competences of the students, (2) the data shows the gap on the result of students' competence between the evaluation given by the experts and the respondents at around $-0.500---+6.50$ for the ability to understand the structure of short stories, compare short stories, analyze short stories, identify short stories, evaluate short stories, interpret the meaning of short stories, produce appropriate short stories based on the correct structure, make some reviews of short stories, convert short stories into other text types based on the correct text structure.

The gap on the results of evaluation given by the experts and the respondents does not go beyond the tolerable gap value as stated by Djiwandono [12]. Besides, there was no expert nor respondent who gave score 1 for the quality of students' competence. An agreement has been reached between the experts' perception and respondents' perception. Thus, it can be implied that the developed authentic assessment instruments to measure students' competence on short story production and appreciation has been considered practical, accurate (reliable), objective and effective.

The conclusion is drawn based on the result of the evaluation form experts and respondents that has reached an agreement. It is also supported by Brown [13] that evaluation made using a set of rubric is reliable when the scores given by several raters are consistent (inter-rater reliability). Based on the result of Cronbach Alpha's test using SPSS 16, the inter-rater reliability is found at 0.99 for understanding the structure of short stories, 0.99 for comparing short stories, 0.99 for evaluating short stories, 0.99 for analyzing short stories, 0.99 for identifying short stories, 9.99 for interpreting the meaning of short stories, 0.99 for producing short stories, 0.99 for editing short stories, 0.99 for making reviews of short stories, and 0.99 for converting short stories into other text types. Hence, it can be drawn into conclusion that the developed product is highly reliable for 0.99 is greater than 0.70 .

Seen from the appropriateness aspect, the authentic assessment instrument developed in this study has been considered appropriate to use for it has fulfilled the validity, reliability, and practicality criteria to use. In addition, the final scoring system used in the developed product is expressed in a scale of $1-100$. Score $81-100$ for highly competent category, $61-80$ for the competent category, 41-60 for the fairly competent category, 21-40 for low competent category, and $0-20$ for the incompetent category.

\section{CONCLUSIONS}

\section{A. Conclusions}

Regarding to the results of this study as presented in the previous chapters, some conclusions are drawn as follows:

1) Based on the result of the teachers' needs analysis on the necessity to use authentic assessment instrument to measure students' competence on short story production and appreciation showed that all of the teachers agreed toward the necessity of this matter. They needed a set of an authentic assessment 
instrument that is complete, accurate, practical, and easy to use.

2) The developed authentic assessment instrument in this study has been considered valid seen from some aspects including the appropriateness of the product with the theories on assessment, the content of the instrument, and the language use. This product has been validated by an expert of assessment who evaluated the product from the validity, reliability, evaluation criteria and the scoring system. An expert of content has also validated the product by evaluating the correctness of the materials. The language use in the instrument has also been validated by an expert of language who gave a good score for the readability of the instrument.

3) The practicality of this product has been considered high based on the result of the questionnaires distributed to the teachers. The result of the questionnaires shows that the developed product is practical to measure students' competence and has been considered effective, accurate (reliable), and objective. In addition, this product has been considered usable and precise in measuring students' competence on short story production and appreciation. The result of the data analysis also shows that the correlation value of the scores is found at 0.985 which is greater than 0.5 .

4) The developed product of this study entitled "Authentic Assessment Instrument to Measure Students' Competence on Short Story Production and Appreciation for Indonesian Language Course of High School" has been considered appropriate to use, especially for Indonesian language teachers of SMA YPI Tunas Bangsa Palembang to measure students' competence on short story production and appreciation.

\section{B. Suggestions}

Regarding to the result of the discussion, some suggestions are proposed as follows.

1) Teachers are suggested to enhance their knowledge and skill on how to assess students' competence on short story production and appreciation.

2) Teachers should also implement fair and objective evaluation in assessing students' competence using a set of valid, reliable and practical authentic assessment instrument.

3) Future researchers are encouraged to develop this product by modifying and completing this product for better quality.

\section{REFERENCES}

Kunandar. 2013. Penilaian Autentik (Penilaian Hasil Belajar Peserta Didik Berdasarkan Kurikulum 2013). Jakarta: Raja Grafindo Persada.

Agustina, Vina Fatimah. 2013. "Pengembangan Alat Evaluasi Menyimak Apresiatif Novel pada Mata Pelajaran Bahasa Indonesia untuk SMP Kelas VII Semester 2 SMP Negeri 1 Bandung”. Tesis. Bandung: Jurusan Pendidikan Bahasa dan Sastra Indonesia Fakultas Pendidikan Bahasa dan Seni, Universitas Pendidikan Indonesia.

Suriani, Lusi. 2013. "Pengembangan Rubrik Penilaian Kemampuan Manulis Karangan Nonfiksi Mata Pelajaran Bahasa Indonesia di SMA Negeri 3 Pagaralam". Tesis. Palembang: Program Studi Magister Pendidikan Bahasa Bidang Kajian Utama Bahasa Indonesia, Fakultas Keguruan dan Ilmu Pendidikan, Universitas Sriwijaya

Akker, J.V.D. 1999. Principle and Methods of Development Research. In T. Van Den Akker, R Brach, K. Gustafson N. Nieven and Tj Plomp (Eds). Design Methodology and Development Research. Diorseedt: Kluwer.

Tessmer, M. 1993. Planning and Conducting Formative Evaluations. London: Kogan Page.

Heaton, J.B. 1975. Writing English Language Twsts A Practical Guide for Teachers of English as a Second or Foreign Languge. Longman Publishing Group.

Djaali dan Puji Muljono, 2008. Pengukuran dalam Bidang Pendidikan, Jakarta: Grasindo.

Permendikbud No.104 Tahun 2014 tantang Penilaian Hasil Belajar oleh Pendidik pada Pendidikan Dasar dan Pendidikan Menengah.

Direktorat Pembinaan SMA. 2010. Petunjuk Teknis Pengembangan Buku Ajar SMA. Jakarta: Kementerian Pendidikan dan Kebudayaan.

Permendikbud No.59 Tahun 2014 tentang Kurikulum 2013 Sekolah Menengah Atas/ Madrasah Aliyah.

Supardi. 2015. Penilaian Autentik. Pembelajaran Afektif, Kognitif Psikomotor (Konsep dan Aplikasi). Jakarta: PT Raja Grafindo Persada.

Djiwandono, S. 2011. Tes Bahasa: Pegangan Bagi Pengajar Bahasa. Malang: Indeks.

Brown, H.D. 2004. Language Assesment: Principles and Classroom Practices. New York: Longman. 